\title{
Performance of Sweet Corn (Zea mays L. saccharata) Varieties under Varying Phosphorus Levels
}

\author{
Wasim Khan ${ }^{1}$, Abhishek Sagar ${ }^{1 *}$, M. Madhu ${ }^{2}$ and M. Sekhar ${ }^{1}$ \\ ${ }^{1}$ Department of Agronomy, ${ }^{2}$ Department of Computer Engineering, \\ SHUATS, Prayagraj, India \\ *Corresponding author
}

\begin{abstract}
A B S T R A C T
\section{Keywords}

Sweet corn,

Varieties,

Phosphorus levels

Article Info

Accepted:

12 August 2020

Available Online:

10 September 2020

A field experiment was conducted during kharif 2016 at Crop Research Farm, Department of Agronomy, SHUATS, Prayagraj, (U.P.). The soil of experimental plot was sandy loam in texture, nearly neutral in soil reaction $(\mathrm{pH} 6.7)$, low in organic carbon $(0.35 \%)$, available $\mathrm{N}$ (230 kg ha $\left.{ }^{-1}\right)$, available $\mathrm{P}\left(20 \mathrm{~kg} \mathrm{ha}^{-1}\right)$ and available $\mathrm{K}\left(189 \mathrm{~kg} \mathrm{ha}^{-1}\right)$. The treatment consisted of 5 levels of Phosphorus viz. $\mathrm{P}_{1}\left(40 \mathrm{~kg} \mathrm{P}_{2} \mathrm{O}_{5} \mathrm{ha}^{-1}\right), \mathrm{P}_{2}\left(50 \mathrm{~kg} \mathrm{P}_{2} \mathrm{O}_{5}\right.$ ha $^{-}$ $\left.{ }^{1}\right), \mathrm{P}_{3}\left(60 \mathrm{~kg} \mathrm{P}_{2} \mathrm{O}_{5} \mathrm{ha}^{-1}\right) \mathrm{P}_{4}\left(70 \mathrm{~kg} \mathrm{P}_{2} \mathrm{O}_{5} \mathrm{ha}^{-1}\right)$ and $\mathrm{P}_{5}\left(80 \mathrm{~kg} \mathrm{P}_{2} \mathrm{O}_{5}\right.$ ha $\left.{ }^{-1}\right)$ whose effect is observed on sweet corn varieties viz. $\mathrm{V}_{1}$ (Sweet Glory) and $\mathrm{V}_{2}$ (Sweety). There were 10 treatments each replicated thrice. The experiment was laid out in Randomized Block Design. The result showed that growth parameters viz., plant height $(213.00 \mathrm{~cm})$ at 80 DAS, number of green leaves plant ${ }^{-1}(5.87)$ at 40 DAS, Dry weight $(200.77 \mathrm{~g})$ at 80 DAS and CGR (32.52 $\mathrm{g} \mathrm{m}^{-2}$ day $^{-1}$ ) at 80 DAS and yield and yield attributes viz., cob weight with husk (325.27 g), cob weight without husk (250.30 g), No. of seeds row $^{-1}$ (35.30), No. of seed rows $\mathrm{cob}^{-1}$ (15.80), No. of seeds $\mathrm{cob}^{-1}$ (500.53), 100-Grain Weight (23.93 g), Green cob Yield $\left(5.32 \mathrm{t} \mathrm{ha}^{-1}\right)$ and Green fodder Yield $\left(13.45 \mathrm{t} \mathrm{ha}^{-1}\right)$ were recorded maximum in treatment $\mathrm{T}_{8}$ (Sweety $+60 \mathrm{~kg} \mathrm{P}_{2} \mathrm{O}_{5} \mathrm{ha}^{-1}$ ). Maximum net return of ₹ 80134.91 and B.C. ratio 2.77 was recorded in treatment $\mathrm{T}_{8}$ (Sweety $+60 \mathrm{~kg} \mathrm{P}_{2} \mathrm{O}_{5} \mathrm{ha}^{-1}$ ).
\end{abstract}

\section{Introduction}

Maize (Zea mays) is a $\mathrm{C}_{4}$ plant and has high yielding potential. It is important crop in the world grown in more than 150 countries having 600 million ha area with 600 million ton of production. The major maize producing countries are USA, China, Brazil, Mexico, France and India. USA has the largest area and production in the world. Italy having highest productivity in the world $9600 \mathrm{~kg} \mathrm{ha}^{-1}$ followed by France with $8800 \mathrm{~kg} \mathrm{ha}^{-1}$. India stand is 5 position in total area, fourth in total production and third in yield per hectare after USA China, Brazil and Mexico but with regards to production its rank eleventh. It is a widely grown cereal and is categorized as primary staple food in many developing countries. India contributes merely about 2.5 percent in world maize production. It is third most important cereal crop after rice and wheat and is being grown throughout the year but mainly as kharif crop. At present maize is being grown in most of the states of the 
country with annual grain production of 24.53 million tonnes and productivity $2583 \mathrm{~kg} \mathrm{ha}^{-1}$. The maize is cultivated throughout the year in all states of the country for various purposes including grain, fodder, green cobs, sweet corn, baby corn, popcorn in peri-urban areas. Special corn viz., sweet corn, popcorn, baby corn, high-oil corn etc. assume tremendous market potential not only in the international market but also in India. These corns with their high market value are perfectly suitable to peri-urban agriculture. Thus they promise higher income to maize growers. Out of the various special corn, sweet corn (Zea mays L. saccharata) has a big market potential. It is a hybridized variety of maize specifically bred to increase the sugar content. Sustainability of scientific sweet corn cultivation practices must be ensured to attain the goal of agricultural sustainability. Its consumption at immature stage as roasted and boiled ears is a popular practice as the kernels are sweet (12$20 \%$ sugar). After harvest green cobs, the plant of sweet corn are used green fresh or dry fodder and now a day's its cultivation is the first choice of the farmers. Maize is an exhaustive crop and requires high quantities of nitrogen and phosphorus. Low soil fertility is one of the bottlenecks to sustain agricultural production and productivity in India. Judicious use of fertilizers play an important role to boost up the productivity of maize, they alone can contribute 40-60 percent of the crop yield (Dayanand, 1998).

Among nutrient elements, phosphorus plays a vital role besides nitrogen in plant nutrient that influences vigour of plant, root growth and improves the quality of crop yield. Phosphorus is an essential factor for cell division because it is a constituent element of nucleoproteins which are involved in the cell reproduction processes. It is also a component of a chemical essential to the reactions of carbohydrate synthesis and degradation. It is important for seed and fruit formation and crop maturation. Phosphorus hastens the ripening of fruits thus counteracting the effect of excess nitrogen application to the soil. It helps to strengthen the skeletal structure of the plant thereby preventing lodging. It also affects the quality of the grains and it may increase the plant resistance to diseases.

Since the phosphate availability is usually low in the soils, the plants have developed special adaptations to acquire the same with the help of multiple high affinity transporters (Raghothama, 1999). The needs of a sweet corn crop for supplemental nutrient can vary greatly among field's seasons and crop growing conditions. Hence, there is need to evaluate sweet corn varieties under optimum phosphorus fertilization under prevailing agro climatic conditions.

\section{Materials and Methods}

The experiment was conducted during the kharif season of 2016 at the Crop Research Farm, Department of Agronomy, Sam Higginbottom University of Agriculture, Technology and Sciences (SHUATS), Allahabad. The Crop Research Farm is situated at $25^{\circ} 57^{\prime} \mathrm{N}$ latitude, $87^{\circ} 19^{\prime} \mathrm{E}$ longitude and at an altitude of $98 \mathrm{~m}$ above mean sea level. The soil of experimental plot was sandy loam in texture, neutral in soil reaction $(\mathrm{pH} 7.5)$, low in organic carbon $(0.35 \%)$, available $\mathrm{N}\left(230 \mathrm{~kg} \mathrm{ha}^{-1}\right)$, available $\mathrm{P}$ (20 kg ha ${ }^{-1}$ ) and available $\mathrm{K}\left(98 \mathrm{~kg} \mathrm{ha}^{-1}\right)$. The treatments comprised of 5 levels of Phosphorus viz. $\mathrm{P}_{1}\left(40 \mathrm{~kg} \mathrm{P}_{2} \mathrm{O}_{5} \mathrm{ha}^{-1}\right), \mathrm{P}_{2}(50$

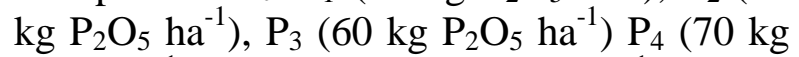
$\left.\mathrm{P}_{2} \mathrm{O}_{5} \mathrm{ha}^{-1}\right)$ and $\mathrm{P}_{5}\left(80 \mathrm{~kg} \mathrm{P}_{2} \mathrm{O}_{5} \mathrm{ha}^{-1}\right)$ whose effect is observed on sweet corn varieties viz. $\mathrm{V}_{1}$ (Sweet Glory) and $\mathrm{V}_{2}$ (Sweety). There were 10 treatments each replicated thrice. The experiment was laid out in Randomized Block Design. Pre-harvest observation viz. Plant height, green leaves plant ${ }^{-1}$, dry weight, Crop Growth Rate and Relative Growth Rate were 
recorded. Post- harvest observation viz. Cobs plant $^{-1}$, Cob length, Cob weight With husk, Cob weight Without husk, Seeds row $^{-1}$, Seeds row $\mathrm{cob}^{-1}$, Seeds $\mathrm{cob}^{-1}$, 100-Grain weight, Green cob yield and Green fodder yield were also recorded. In addition to pre and postharvest observation, economics of treatments was also studied to find out the best treatment combination for higher yield, maximum net return and highest $\mathrm{B}$ : $\mathrm{C}$ ratio of sweet corn.

\section{Results and Discussion}

\section{Performance of Varieties}

Among both varieties 'Sweety' significantly recorded maximum plant height at 80 DAS, Dry weight at 80 DAS and CGR at 80 DAS whereas, cob weight with husk, cob weight without husk, No. of seeds row ${ }^{-1}$, No. of seed rows $\mathrm{cob}^{-1}$, No. of seeds $\mathrm{cob}^{-1}$, 100-Grain Weight, Green cob Yield and Green fodder Yield as compared to 'Sweet Glory'. However, Green leaves plant ${ }^{-1}$, RGR, Cob length and number of cobs plant ${ }^{-1}$ were found to be non- significant (Table 1). The maximum plant height $(213.00 \mathrm{~cm})$ at 80 DAS, Dry weight $(200.77 \mathrm{~g})$ at 80 DAS and CGR (32.52 $\mathrm{g} \mathrm{m}^{-2} \mathrm{day}^{-1}$ ) at 80 DAS (Table 2) whereas, cob weight with husk (325.27 g), cob weight without husk $(250.30 \mathrm{~g})$, No. of seeds row ${ }^{-1}$ (35.30), No. of seed rows $\mathrm{cob}^{-1}$ (15.80), No. of seeds $\mathrm{cob}^{-1}$ (500.53), 100Grain Weight (23.93 g), Green cob Yield $\left(5.32 \mathrm{t} \mathrm{ha}^{-1}\right)$ and Green fodder Yield (13.45 t $\mathrm{ha}^{-1}$ ) were recorded in 'Sweety' variety as compared to 'Sweet glory' variety (Table 3). Under present investigation the better performance of 'Sweety' seems to be on account of higher uptake of nitrogen and phosphorus from soil and its reallocation in grain and plant.

The higher availability of nitrogen and phosphorus seems to have promoted development of morphological structure by virtue of multiplication of cell division which is well reflected through increased crop growth rate (Kumar, 2008).

\section{Effect of phosphorus levels}

Growth attributes viz., plant height, Dry weight and CGR likewise, yield and yield attributes viz., cob weight with husk, cob weight without husk, No. of seeds row ${ }^{-1}$, No. of seed rows $\mathrm{cob}^{-1}$, No. of seeds $\mathrm{cob}^{-1}, 100$ Grain Weight, Green cob Yield and Green fodder Yield increased significantly in treatment $\mathrm{T}_{8}$ with the application of $60 \mathrm{~kg}$ $\mathrm{P}_{2} \mathrm{O}_{5}$ ha $^{-1}$ (Table 2 \& Table 3). However, number of green leaves plant ${ }^{-1}$, RGR, Cob length and number of cob plant ${ }^{-1}$ were found to be non-significant with the application 60 $\mathrm{kg} \mathrm{P}_{2} \mathrm{O}_{5}$ ha $^{-1}$ (Table 1).

The maximum plant height $(213.00 \mathrm{~cm})$ at 80 DAS, Dry weight (200.77 g) at 80 DAS, cob weight without husk (250.30 g), No. of seeds row $^{-1}$ (35.30), 100-Grain Weight (23.93 g), Green cob Yield (5.32 $\left.\mathrm{t} \mathrm{ha}^{-1}\right)$ and Green fodder Yield (13.45 $\mathrm{t} \mathrm{ha}^{-1}$ ) were recorded in treatment $\mathrm{T}_{8}$ with the application of $60 \mathrm{~kg}$ $\mathrm{P}_{2} \mathrm{O}_{5}$ ha $^{-1}$ followed by treatment $\mathrm{T}_{5}$ and it was found to be at par to treatment $\mathrm{T}_{8}$ (Table $2 \&$ Table 3) whereas, CGR (32.52 $\mathrm{g} \mathrm{m}^{-2} \mathrm{day}^{-1}$ ) at 80 DAS was recorded in treatment $\mathrm{T}_{8}$ with the application of $60 \mathrm{~kg} \mathrm{P}_{2} \mathrm{O}_{5} \mathrm{ha}^{-1}$ followed by treatment $T_{5}$ and $T_{4}$ it was found to be at par to treatment $\mathrm{T}_{8}$ (Table 2) and cob weight with husk $(325.27 \mathrm{~g})$, No. of seed rows $\mathrm{cob}^{-1}$ (15.80), No. of seeds $\mathrm{cob}^{-1}$ (500.53) were recorded in treatment $\mathrm{T}_{8}$ with the application of $60 \mathrm{~kg} \mathrm{P}_{2} \mathrm{O}_{5} \mathrm{ha}^{-1}$ followed by treatment $\mathrm{T}_{7}$ and it was found to be at par to treatment $\mathrm{T}_{8}$ (Table 3). Application of 120-60 kg N-P $\mathrm{O}_{5}$ $\mathrm{ha}^{-1}$ might have increased interception, absorption and utilization of radiant energy which in turn increased photosynthesis and thereby plant height and finally accumulation of dry matter. 
Table.1 Effect of different Phosphorus levels on Green leaves plant ${ }^{-1}$, RGR, cobs plant ${ }^{-1}$ and Cob length of Sweet corn varieties

\begin{tabular}{|c|c|c|c|c|c|}
\hline \multicolumn{2}{|r|}{ Treatments } & \multirow{2}{*}{$\begin{array}{c}\text { Green leaves } \\
\text { plant }^{-1} \text { at } 80 \\
\text { DAS } \\
8.53\end{array}$} & \multirow{2}{*}{$\begin{array}{c}\text { RGR at } \\
\text { 80 DAS } \\
0.04\end{array}$} & \multirow{2}{*}{$\begin{array}{c}\begin{array}{c}\text { Cobs } \\
\text { plant }^{-1}\end{array} \\
1.00 \\
\end{array}$} & \multirow{2}{*}{$\begin{array}{r}\begin{array}{c}\text { Cob } \\
\text { length }\end{array} \\
16.00\end{array}$} \\
\hline $\mathrm{T}_{1}$ & Sweet Glory $+40 \mathrm{~kg} \mathrm{P}_{2} \mathrm{O}_{5} \mathrm{ha}^{-1}$ & & & & \\
\hline $\mathrm{T}_{2}$ & Sweet Glory $+50 \mathrm{~kg} \mathrm{P}_{2} \mathrm{O}_{5} \mathrm{ha}^{-1}$ & 8.60 & 0.04 & 1.07 & 17.50 \\
\hline $\mathrm{T}_{3}$ & Sweet Glory $+60 \mathrm{~kg} \mathrm{P}_{2} \mathrm{O}_{5} \mathrm{ha}^{-1}$ & 8.67 & 0.03 & 1.20 & 18.00 \\
\hline $\mathrm{T}_{4}$ & Sweet Glory $+70 \mathrm{~kg} \mathrm{P}_{2} \mathrm{O}_{5} \mathrm{ha}^{-1}$ & 8.73 & 0.03 & 1.20 & 18.03 \\
\hline $\mathrm{T}_{5}$ & Sweet Glory $+80 \mathrm{~kg} \mathrm{P}_{2} \mathrm{O}_{5} \mathrm{ha}^{-1}$ & 8.80 & 0.03 & 1.20 & 18.07 \\
\hline $\mathrm{T}_{6}$ & Sweety $+40 \mathrm{~kg} \mathrm{P}_{2} \mathrm{O}_{5} \mathrm{ha}^{-1}$ & 8.60 & 0.04 & 1.00 & 16.20 \\
\hline $\mathrm{T}_{7}$ & Sweety $+50 \mathrm{~kg} \mathrm{P}_{2} \mathrm{O}_{5} \mathrm{ha}^{-1}$ & 8.67 & 0.03 & 1.00 & 17.70 \\
\hline $\mathrm{T}_{8}$ & Sweety $+60 \mathrm{~kg} \mathrm{P}_{2} \mathrm{O}_{5} \mathrm{ha}^{-1}$ & 8.73 & 0.03 & 1.20 & 18.20 \\
\hline $\mathrm{T}_{9}$ & Sweety $+70 \mathrm{~kg} \mathrm{P}_{2} \mathrm{O}_{5} \mathrm{ha}^{-1}$ & 8.80 & 0.03 & 1.20 & 18.23 \\
\hline $\mathrm{T}_{10}$ & Sweety $+80 \mathrm{~kg} \mathrm{P}_{2} \mathrm{O}_{5} \mathrm{ha}^{-1}$ & 8.87 & 0.03 & 1.20 & 18.27 \\
\hline & F- test & NS & NS & NS & NS \\
\hline & S. Ed. $( \pm)$ & 0.201 & 0.002 & 0.128 & 1.173 \\
\hline & C. D. $(P=0.05)$ & 0.416 & 0.004 & 0.263 & 2.421 \\
\hline
\end{tabular}

Table.2 Effect of different phosphorus levels on plant height, dry weight and CGR of Sweet corn varieties

\begin{tabular}{|c|c|c|c|c|}
\hline \multicolumn{2}{|r|}{ Treatments } & \multirow{2}{*}{$\begin{array}{c}\text { Plant height } \\
\text { At 80 DAS } \\
191.60\end{array}$} & \multirow{2}{*}{$\begin{array}{c}\text { Dry weight } \\
\text { At } 80 \text { DAS } \\
157.75\end{array}$} & \multirow{2}{*}{$\begin{array}{c}\text { CGR } \\
\text { At } 80 \text { DAS } \\
27.45\end{array}$} \\
\hline $\mathrm{T}_{1}$ & Sweet Glory $+40 \mathrm{~kg} \mathrm{P}_{2} \mathrm{O}_{5} \mathrm{ha}^{-1}$ & & & \\
\hline $\mathrm{T}_{2}$ & Sweet Glory $+50 \mathrm{~kg} \mathrm{P}_{2} \mathrm{O}_{5} \mathrm{ha}^{-1}$ & 202.27 & 182.21 & 30.44 \\
\hline $\mathrm{T}_{3}$ & Sweet Glory $+60 \mathrm{~kg} \mathrm{P}_{2} \mathrm{O}_{5} \mathrm{ha}^{-1}$ & 212.47 & 197.02 & 32.32 \\
\hline $\mathrm{T}_{4}$ & Sweet Glory $+70 \mathrm{~kg} \mathrm{P}_{2} \mathrm{O}_{5} \mathrm{ha}^{-1}$ & 212.52 & 197.05 & 32.33 \\
\hline $\mathrm{T}_{5}$ & Sweet Glory $+80 \mathrm{~kg} \mathrm{P}_{2} \mathrm{O}_{5} \mathrm{ha}^{-1}$ & 212.53 & 197.06 & 32.33 \\
\hline $\mathrm{T}_{6}$ & Sweety $+40 \mathrm{~kg} \mathrm{P}_{2} \mathrm{O}_{5} \mathrm{ha}^{-1}$ & 194.87 & 162.98 & 27.57 \\
\hline $\mathrm{T}_{7}$ & Sweety $+50 \mathrm{~kg} \mathrm{P}_{2} \mathrm{O}_{5} \mathrm{ha}^{-1}$ & 203.77 & 185.02 & 29.70 \\
\hline $\mathrm{T}_{8}$ & Sweety $+60 \mathrm{~kg} \mathrm{P}_{2} \mathrm{O}_{5} \mathrm{ha}^{-1}$ & 213.00 & 200.77 & 32.52 \\
\hline $\mathrm{T}_{9}$ & Sweety $+70 \mathrm{~kg} \mathrm{P}_{2} \mathrm{O}_{5} \mathrm{ha}^{-1}$ & 213.13 & 200.80 & 32.53 \\
\hline $\mathrm{T}_{10}$ & Sweety $+80 \mathrm{~kg} \mathrm{P}_{2} \mathrm{O}_{5} \mathrm{ha}^{-1}$ & 213.17 & 200.82 & 32.53 \\
\hline \multicolumn{2}{|r|}{ F- test } & $\mathrm{S}$ & $\mathrm{S}$ & $\mathrm{S}$ \\
\hline \multicolumn{2}{|r|}{ S. Ed. $( \pm)$} & 5.356 & 2.024 & 1.022 \\
\hline \multicolumn{2}{|r|}{ C. D. $(P=0.05)$} & 11.055 & 4.178 & 2.109 \\
\hline
\end{tabular}


Table.3 Effect of different phosphorus levels on Cob weight with husk, Cob weight without husk, Seeds row ${ }^{-1}$, Seed rows cob ${ }^{-1}$, Seeds $\mathrm{cob}^{-1}, 100$ - Grain Weight, Green cob Yield and Green fodder Yield of Sweet corn varieties

\begin{tabular}{|c|c|c|c|c|c|c|c|c|c|}
\hline \multicolumn{2}{|c|}{ Treatments } & \multirow{2}{*}{$\begin{array}{c}\text { Cob } \\
\text { weight } \\
\text { with } \\
\text { husk } \\
\text { (g) } \\
230.47\end{array}$} & \multirow{2}{*}{$\begin{array}{c}\text { Cob } \\
\text { weight } \\
\text { without } \\
\text { husk } \\
\text { (g) } \\
180.80\end{array}$} & \multirow{2}{*}{$\begin{array}{l}\begin{array}{c}\text { Seeds } \\
\text { row }^{-1}\end{array} \\
29.27\end{array}$} & \multirow{2}{*}{$\begin{array}{l}\text { Seed } \\
\text { rows } \\
\text { cob }^{-1} \\
\\
14.47\end{array}$} & \multirow{2}{*}{$\begin{array}{c}\begin{array}{c}\text { Seeds } \\
\text { cob }^{-1}\end{array} \\
423.53\end{array}$} & \multirow{2}{*}{$\begin{array}{c}\begin{array}{c}\text { 100- } \\
\text { Grain } \\
\text { Weight } \\
\text { (g) }\end{array} \\
21.63\end{array}$} & \multirow{2}{*}{$\begin{array}{c}\text { Green cob } \\
\text { Yield }\left(\mathbf{t ~ h a}^{-1}\right) \\
\\
5.03\end{array}$} & \multirow{2}{*}{$\begin{array}{l}\begin{array}{c}\text { Green } \\
\text { fodder } \\
\text { Yield } \\
\left(\mathbf{t ~ h a}^{-1}\right)\end{array} \\
11.84\end{array}$} \\
\hline $\mathrm{T}_{1}$ & Sweet Glory $+40 \mathrm{~kg} \mathrm{P}_{2} \mathrm{O}_{5} \mathrm{ha}^{-1}$ & & & & & & & & \\
\hline $\mathrm{T}_{2}$ & Sweet Glory $+50 \mathrm{~kg} \mathrm{P}_{2} \mathrm{O}_{5} \mathrm{ha}^{-1}$ & 270.47 & 210.80 & 32.77 & 14.67 & 448.80 & 22.73 & 5.15 & 12.87 \\
\hline $\mathrm{T}_{3}$ & Sweet Glory $+60 \mathrm{~kg} \mathrm{P}_{2} \mathrm{O}_{5} \mathrm{ha}^{-1}$ & 295.97 & 231.05 & 34.03 & 15.07 & 463.73 & 23.63 & 5.32 & 13.44 \\
\hline $\mathrm{T}_{4}$ & Sweet Glory $+70 \mathrm{~kg} \mathrm{P}_{2} \mathrm{O}_{5} \mathrm{ha}^{-1}$ & 296.00 & 231.07 & 34.10 & 15.13 & 463.77 & 23.67 & 5.32 & 13.45 \\
\hline $\mathrm{T}_{5}$ & Sweet Glory $+80 \mathrm{~kg} \mathrm{P}_{2} \mathrm{O}_{5} \mathrm{ha}^{-1}$ & 296.00 & 231.08 & 34.13 & 15.17 & 463.80 & 23.67 & 5.32 & 13.45 \\
\hline $\mathrm{T}_{6}$ & Sweety $+40 \mathrm{~kg} \mathrm{P}_{2} \mathrm{O}_{5} \mathrm{ha}^{-1}$ & 280.00 & 200.00 & 29.67 & 15.00 & 460.00 & 21.90 & 5.04 & 11.85 \\
\hline $\mathrm{T}_{7}$ & Sweety $+50 \mathrm{~kg} \mathrm{P}_{2} \mathrm{O}_{5} \mathrm{ha}^{-1}$ & 310.00 & 230.30 & 33.00 & 15.40 & 485.47 & 22.93 & 5.16 & 12.88 \\
\hline $\mathrm{T}_{8}$ & Sweety $+60 \mathrm{~kg} \mathrm{P}_{2} \mathrm{O}_{5} \mathrm{ha}^{-1}$ & 325.27 & 250.30 & 35.30 & 15.80 & 500.53 & 23.93 & 5.32 & 13.45 \\
\hline $\mathrm{T}_{9}$ & Sweety $+70 \mathrm{~kg} \mathrm{P}_{2} \mathrm{O}_{5} \mathrm{ha}^{-1}$ & 325.30 & 250.33 & 35.37 & 15.83 & 500.57 & 23.97 & 5.33 & 13.46 \\
\hline $\mathrm{T}_{10}$ & Sweety $+80 \mathrm{~kg} \mathrm{P}_{2} \mathrm{O}_{5} \mathrm{ha}^{-1}$ & 325.33 & 250.35 & 35.40 & 15.87 & 500.60 & 24.00 & 5.33 & 13.46 \\
\hline & F- test & $\mathrm{S}$ & $\mathrm{S}$ & $\mathrm{S}$ & $\mathrm{S}$ & $\mathrm{S}$ & $\mathrm{S}$ & $\mathrm{S}$ & $\mathrm{S}$ \\
\hline & S. Ed. $( \pm)$ & 15.913 & 9.400 & 1.408 & 0.219 & 9.658 & 0.623 & 0.10 & 0.21 \\
\hline & C. D. $(P=0.05)$ & 32.844 & 19.75 & 2.906 & 0.452 & 19.934 & 1.286 & 0.21 & 0.44 \\
\hline
\end{tabular}


Table.4 Effect of sweet corn varieties and phosphorus levels on economics of treatment

\begin{tabular}{|c|c|c|c|c|c|c|c|c|}
\hline \multirow[b]{2}{*}{ Treatments } & \multirow[b]{2}{*}{ Cost of Cultivation } & \multicolumn{2}{|c|}{ Yield } & \multicolumn{2}{|c|}{ Sale rate (₹) } & \multirow{2}{*}{$\begin{array}{c}\text { Gross } \\
\text { return } \\
\left(₹ \mathbf{h a}^{-1}\right)\end{array}$} & \multirow{2}{*}{$\begin{array}{l}\text { Net return } \\
\left(₹ \mathbf{h a}^{-1}\right)\end{array}$} & \multirow[t]{2}{*}{ B:C ratio } \\
\hline & & Yield (t ha $\left.{ }^{-1}\right)$ & $\begin{array}{l}\text { Green } \\
\text { Fodder } \\
\left.(\mathbf{t ~ h a})^{-1}\right)\end{array}$ & $\begin{array}{c}\text { Green } \\
\text { Cob } \\
\left(\mathbf{t} \mathbf{h a}^{-1}\right)\end{array}$ & $\begin{array}{c}\text { Green } \\
\text { Fodder } \\
\left(\mathbf{t ~ h a}^{-1}\right)\end{array}$ & & & \\
\hline $\mathrm{T}_{1}$ & 44261.61 & 5.03 & 11.84 & 80480 & 35520 & 116000 & 71738.39 & 2.62 \\
\hline $\mathrm{T}_{2}$ & 44826.85 & 5.15 & 12.87 & 82240 & 38610 & 120850 & 76023.15 & 2.70 \\
\hline $\mathrm{T}_{3}$ & 45392.09 & 5.32 & 13.44 & 84960 & 40320 & 125280 & 79887.91 & 2.76 \\
\hline $\mathrm{T}_{4}$ & 45957.33 & 5.32 & 13.45 & 85120 & 40350 & 125470 & 79512.67 & 2.73 \\
\hline $\mathrm{T}_{5}$ & 46522.57 & 5.32 & 13.45 & 85120 & 40350 & 125470 & 78947.43 & 2.70 \\
\hline $\mathrm{T}_{6}$ & 44261.61 & 5.04 & 11.85 & 80640 & 35550 & 116190 & 71928.39 & 2.63 \\
\hline $\mathrm{T}_{7}$ & 44826.85 & 5.16 & 12.88 & 82560 & 38640 & 121040 & 76213.15 & 2.70 \\
\hline $\mathrm{T}_{8}$ & 45392.09 & 5.32 & 13.45 & 85120 & 40500 & 125620 & 80227.91 & 2.77 \\
\hline $\mathrm{T}_{9}$ & 45957.33 & 5.33 & 13.46 & 85280 & 40380 & 125470 & 79512.67 & 2.73 \\
\hline $\mathrm{T}_{10}$ & 46522.57 & 5.33 & 13.46 & 85280 & 40380 & 125660 & 79137.43 & 2.70 \\
\hline
\end{tabular}

Selling price of green cob $16000 ₹ / \mathrm{t}$

Selling price of green fodder $3000 ₹ / \mathrm{t}$ 
The enhanced growth with nitrogen was reported by Massey and Gaur (2006) and Khazaei et al., (2010). Significant improvement in overall growth of the crop by virtue of increased photosynthetic efficiency. Thus greater availability of photosynthates, metabolites and nutrients to develop reproductive structures seems to have resulted in increased productive plants, cob length and cob weight with these fertility levels. The present findings are within the close vicinity of those reported by Massey and Guar (2006) and Khazaei et al., (2010). Further increase in nutrient level though increased green cobs and fodder yields but marginal increase in green cob and fodder yields unable to compensate higher prices of fertilizer (Nath et al., 2009).

\section{Economics}

A perusal of the table 4 clearly revels that treatment $\mathrm{T}_{8}$ recorded maximum net return of (₹80227.91), followed by treatment $T_{3}$ (₹79887.91) giving a $\mathrm{B}: \mathrm{C}$ ratio of (2.77) and (2.76) respectively.

Based on the findings, of this experiment it can be concluded that 'Sweety' is the best and economically profitable variety as compared to 'Sweet Glory' variety. Application of $60 \mathrm{~kg}$ $\mathrm{P}_{2} \mathrm{O}_{5} \mathrm{ha}^{-1}$ as DAP is economically profitable for farmers.

\section{References}

Bhadu, A.S., Kairon, M.S. and Singh, R.P. 2017. Effect of plant population and $\mathrm{N}$ application on yield and economics of winter maize. Indian Journal of Agronomy 34(4): 393-395.

Brar, N.S., R.S., Singh, T. and Yadav, S.K. 2016. Effect of irrigation and fertility levels on nitrogen and phosphorus uptake in winter maize under shallow water table conditions in Haryana. Indian Journal of Soil Conservation 29(2): 135-136.

Damor, N., Patel, G.N., Patel, N.I. and Patel, C.K. 2017. Response of rabi maize (Zea mays L.) to different dates of sowing and fertility levels. International Journal of Science, Environment 6(3): 1905 - 1911.

Dayanand. 1998. Principles governing maize cultivation during rainy season. Indian Farming, 48(1):84-87.

Dhaka, S.K., Dhewa, J. and Gautam, R.C. 2014. Performance of maize varieties at varying plant densities. Annals of Agricultural Research 18(3): 375-376

Khazaei, F., Alikhani, M.A., Yari, I. and Khandan, A. 2010. Study the correlation, regression and path coefficient analysis in sweet corn (Zea mays var. saccharata) under different levels of plant density and nitrogen rate. Journal of Agricultural and Biological Science, 5(6): 212-216.

Kumar, A. 2008. Growth, yield and water use efficiency of different maize (Zea mays L) based cropping systems under varying planting methods and irrigation levels. Indian Journal of Agricultural Sciences 78(3): 244-47.

Massey, J.X. and Gaur, B.L. 2006. Effect of plant population and fertility levels on growth and NPK uptake by sweet corn (Zea mays L.) cultivars. Annals Agricultural Research New series, 27(4): 365-368.

Nath, K., Nepalia, V. and Singh, D. 2009. Effect of integrated nutrient management on growth and yield of sweet corn (Zea mays ssp. saccharata). Annals of Agricultural Research New Series 30(1\&2): 73-76.

Raghothama, K.G. (1999). Phosphate acquisition. Annual Review of Plant Physiology and Plant Molecular Biology, 50:665-693.

\section{How to cite this article:}

Wasim Khan, Abhishek Sagar, M. Madhu and Sekhar, M. 2020. Performance of Sweet Corn (Zea mays L. saccharata) Varieties under Varying Phosphorus Levels. Int.J.Curr.Microbiol.App.Sci. 9(09): 14551461. doi: https://doi.org/10.20546/ijcmas.2020.909.185 